\title{
Characterization of E-waste: An Inventory from Households and the Recycling Sector in South Eastern Nigeria
}

\section{${ }^{1}$ OKORHI, OJ; ${ }^{2}$ OKEREKA, EE; ${ }^{2}$ IGBINOBA, EI; ${ }^{2}$ ND-EZUMA, AN}

\author{
${ }^{1}$ Institute of Engineering, Technology, and Innovation Management (METI), University of Port Harcourt, Rivers/Science Policy and \\ Innovation Studies (SPIS), National Centre for Technology Management (NACETEM), South East Zonal Office, Enugu, Nigeria. \\ *Corresponding author Email: johnsonokorhi@gmail.com \\ ${ }^{2}$ Materials and Energy Technology (MET) Department, Projects Development Institute (PRODA), Enugu, Nigeria. Email: \\ exotiknuella@yahoo.com, igbinobaedith4life@yahoo.com, mailnedi@yahoo.com
}

\begin{abstract}
This paper presents an inventory of waste electrical and electronic equipment (WEEE) and opportunities for the recycling sector in South Eastern Nigeria. The outcomes reveals that there are about 128 types of WEEE which fell into ten distinct groups. This proffers stakeholders, more especially the regulatory agencies, with a guide in predicting seasonally generated WEEE as well as appropriate approaches adopted as sustainable management strategies.
\end{abstract}

\section{DOI: https://dx.doi.org/10.4314/jasem.v22i1.27}

Copyright: Copyright $@ 2018$ Uzoekwe and Ajaye. This is an open access article distributed under the Creative Commons Attribution License (CCL), which permits unrestricted use, distribution, and reproduction in any medium, provided the original work is properly cited

Dates: Received 12 December 2017; received in revised form 22 December 2017; accepted 31 December 2017

Keywords: Waste electrical and electronic equipment (WEEE), Used electrical and electronic equipment (UEEE), South Eastern Nigeria

Electrical and Electronic Equipment (EEE) has completely transformed today's living, communication, statecraft, corporate businesses, show business, transportation, educational sector, and human health care. This is as result of the exceptional production of consumer electronic products and its usage, specifically with, computing equipment, mobile phones, office electronic equipment, entertainment electronic equipment and other household appliances. A country's economic and social development has been aligned to its access to Information and Communication Technology (ICT) (United Nations, 2011; Okorhi, Amadi-Echendu, Aderemi, and Otejere, 2015a). The variance between developed and developing countries in the provisions offered with information and communication Technology (ICT) is frequently referred to as the "digital divide" (National Environmental Standards and Regulations Enforcement Agency, NESREA, 2011a; Basel Convention, 2011; Okorhi et al., 2015a). In recent times, Nigeria has been experiencing speedy ICT revolution in a move to overcome this "divide" through the importation of used-EEE from developed countries. This quick turn has led to increased utilization of EEE and concurrently a decrease in EEE's lifetime, such that there is an annual increase of $10 \%$ in the volume of waste. (Oh, Lee, Yang, Ha, and Kim, 2003; Ayodeji, 2011). Nigeria still lag in facilities and assets mobilization to sustainably management Waste Electrical and Electronics Equipment (WEEE or ewaste) which arises when these products reaches endof-life (E.o.L). Modernization and inventions in product's manufacturing, likely desuetude of edevices, and cheap pricing for near E.o.L EEE have caused a quick-flooding trend for WEEE worldwide (Okorhi et al., 2015a). WEEE as composite substance is not harmful per se, nonetheless, many e-devices consisting of complex combination of substances and parts which can leach toxins to the environments at their end-of-life.

E-waste is an informal and popular name for Waste Electrical and Electronics Equipment (WEEE). These are waste streams accumulated from used EEE, obsolete EEE and end-of-life EEE. WEEE stay abandoned in households, workplaces, stores/warehouses among others, and sometimes mixing with municipal solid wastes, which are eventually thrown away in open-dumps. (Okorhi, Olamade, Aderemi, Obaze and Abia-Bassey, 2012; Alo, 2009). The mounting volume of WEEE worldwide has become of great concern to many nations which seeks sustainable options to discard used electrical and electronic equipment (UEEE) (Ayodeji, 2011; The Guardian, 2012; Vanguard, 2013). WEEE is now considered a key waste stream under the Year-2011 report of the Basel Convention 
and partners. The volume of thrown away EEE is increasing at a disturbing degree, particularly with developing nations where their markets are flooded with large volumes of EEE. With an annually generated estimate placed at 1.1 million tonnes of WEEE, Nigeria is comparably faced with huge volume of WEEE in West African (Basel Convention, 2011; Okorhi, Amadi-Echendu, Aderemi, 2015). Being one of the highest growing waste streams globally a phenomenal increase in the quantities of disposed WEEE has been noted in several parts of the world, calling for actions from governments, environmental bodies and the scientific group. Estimations put the yearly globally generated volume of WEEE to be approximately 50 million tonnes (Okorhi, 2017). A review of the literature reveals some factors that determines whether, how or when an e-device becomes WEEE. It also noted when and how WEEE should be collected and eventual disposal of. In summary, these factors were mainly debated in seclusion of each other. There was a missing link on the relationship of the factors affecting WEEE generation and handling (interactions from the end-users, entrepreneurs, policy-makers and other stakeholders'views) (Ongondo and Williams, 2011). Most WEEE and near end-of-life EEE smuggled into West African countries are habitually stated, at the country of import, as "used goods" destined as handouts to people or organisations (GFMECD, 1995). Specifically, dealers of recycled automobiles plays a strategic role in trading UEEE and WEEE through co-loading used vehicles designated for distribution in African countries (Basel Convention, 2011). Conferring the year 2011 Basel Report on WEEE, Nigeria was reported to be the leading shipper of UEEE, then trailed by Ghana, with the UK singled out as the main distributing nation of electrical and electronic devices, trailed far behind by France (Basel Convention, 2011). Furthermore, the report showed that for traders of WEEE to camouflage these illicit traffics, the tagging of the consignment is occasionally influenced by assigning deceitful codes for UEEE like fridge-freezers and air conditioners or through the removal of their compressors compartments. Often the port manifests on WEEE shipment are released to port officials lately, a short timing by ship set sailing. From the aforementioned and address delivered by Dr. (Mrs) Ngeri S. Benebo (NESREA, 2011a), the likely factors swaying WEEE generation, collection, intermediate storage and final disposal across Nigeria can be summarized as: there exist a missing link with public education and sensitization on WEEE harmfulness and end-users' common lifestyles of purchasing UEEE and near
E.o.L EEE instead of new ones; the failure of endusers to clear identify and differentiate between WEEE and near E.o.L EEE; the reluctance on the part of government regulatory/control agencies to prohibit the transboundary movements of near endof-life EEE or develop sustainable regulations on imported UEEE to guide the shippers on what makes an item classified as "near end-of-life EEE" and another as "WEEE"; lack of formal recycling facilities for WEEE across Nigeria; failure to compel manufacturers of EEE to institute, practice and pursue take-back programmes on WEEE; deceitful shipment declarations of WEEE as economic goods or "second-hand goods" on shipping manifests; incorrect codes deliberately used for certain items like refrigerators to depicting them as safe for shipment; the act of co-loading WEEE with used automobiles; vague data on influx of new EEE and UEEE circulated in Nigeria; and the available National statistics on WEEE streams are more reflecting on trends in South-west zone. Still, anecdotal reports by Osibanjo and Nnorom (2008), Ongondo and Williams (2011), and Ayodeji (2011) had suggested that there is gradual and steady increase in the quantity of WEEE generated thereby intensifying the interest for recycling to conserve natural resources and protect the environment. Part I - General Provisions, Section 2, Sub-section 3 of the National Environmental (Electrical/Electronics Sector) Regulations S.I. No. 23 of 2011 demands that the principles of these regulations should be anchored on the 5Rs which are: Reduce, Repair, Re-use, Recycling and Recover as the primary drivers of the sector and should encompass all the categories and Electrical and Electronic Equipment listed in Nigeria. Therefore, WEEE suggests important opportunities to generate safe enterprises and employments. It also have substances of significant value like palladium and indium as well as valuable metals like steel, copper, silver and gold. Some of these items could be salvaged, reused or recycled, in that way helping as a potential avenue for ancillary resources, and cut down demands on inadequate raw materials, at the same time minimising the overall footprint on the environment (Dittke, 2009; E-Waste Association of South Africa, eWASA 2009; Basel Convention, 2011). The aim of this paper is to conduct an inventory of WEEE generated from households and the recycling sector in South Eastern Nigeria.

\section{MATERIALS AND METHODS}

Study Area: The 5 states that makeup South Eastern Nigeria (Abia, Anambra, Ebonyi, Enugu and Imo) were surveyed. 
Collection and Collation of WEEE Data: The study group comprised the End-users, Importers/Distributors as well as Monitoring Agencies of EEE/WEEE (Table 1). The End-users, who are the primary consumers of EEE, contributes a sizable amounts of near E.o.L EEE or WEEE to the daily waste streams. The Importers/Distributors are the recyclers and merchandizers, who serve as link through the purchase and sale, between the primary producer and the End-users of EEE. The Monitoring Agencies are trained personnel of government assigned with responsibilities of managing the process of WEEE trends in Nigeria including the monitoring of trans-boundary movement, implementing control measures and final disposal of WEEE (Table 2). For uniform spread in each of the stratum, a local government area (LGA) was purposively chosen from each of the 3 senatorial districts that characterize a state, while the $4^{\text {th }}$ LGA was picked as the state's capital. This is justified by the importance and high association in generation of WEEE and its management. The approach was investigative study through administration of questionnaire. The questionnaire was tailored to ascertain inventory flow on WEEE from the key players. The study identified the types of WEEE that were mostly generated/stockpiled by consumers and at institutions. The key research questions was: What are the categories of WEEE generated in South
Eastern Nigeria? It has sub-research questions like (i) How do you classify imported (Tokunbo) used Electrical/Electronic Equipment (EEE)? Age; Brand; Functioning/ non-functional; Country of import; Value (ii) What kind of electric/electronic waste (WEEE) are you most likely to dispose of? (iii) Please, give an estimate of disused or disposed Electrical/Electronic appliances between 2010 and 2014 (iv) Give a Budget estimate for yearly allocations in managing WEEE between 2010-2014. The volume of WEEE generated annually in South Eastern Nigeria were captured from field measurements and supplemented with secondary data sourced from firms' records and different published sources.

Processing and Analysis of WEEE Data: A proportional analysis was carried out to relate the aim of the study and the assumed hypothesis. In the test for hypothesis, the dependent variable is the question on "encouraging Reuse, source Reduction, Recycling, Repair, Recovery, Landfill and Incineration of waste WEEE". While the independent variables included questions on "Carrying out periodic inventory surveys on types of WEEE generated in the region; Collection, Collating, Processing and storing statistics on generated WEEE; as well as Having adequate periodic documentation on WEEE quantity and budgeting to support management process".

Table 1: Schedule of Questionnaire Administered

\begin{tabular}{lrrrrr}
\hline \multicolumn{1}{c}{ Stakeholders } & $\begin{array}{c}\text { Number } \\
\text { Administered }\end{array}$ & $\begin{array}{c}\text { Number } \\
\text { Retrieved }\end{array}$ & $\begin{array}{c}\% \text { of } \\
\text { Number } \\
\text { Retrieved }\end{array}$ & $\begin{array}{c}\text { Number of Valid } \\
\text { Retrieved } \\
\text { Questionnaire }\end{array}$ & $\begin{array}{c}\% \text { of Valid } \\
\text { Retrieved } \\
\text { Questionnaire }\end{array}$ \\
\hline Monitoring/Control Agencies & 40 & 40 & 100 & 35 & $12.50 \%$ \\
Distributors/ Recyclers & 40 & 29 & 72.5 & 29 & $22.86 \%$ \\
Consumers/End-Users & 200 & 137 & 68.5 & $48.93 \%$ \\
Total & $\mathbf{2 8 0}$ & $\mathbf{2 0 6}$ & $\mathbf{7 3 . 6 \%}$ & $\mathbf{2 0 1}$ & $\mathbf{7 1 . 7 9 \%}$ \\
\hline
\end{tabular}

Table 2: Key Sections of the Questionnaire

\begin{tabular}{|c|c|c|c|c|}
\hline S/No & $\begin{array}{l}\text { Outline of key areas of interest of the } \\
\text { questionnaire for "Characterization of E- } \\
\text { waste" }\end{array}$ & Stakeholder(s) & $\begin{array}{l}\text { Questionnaire } \\
\text { Type } \\
\text { Administered }\end{array}$ & $\begin{array}{c}\text { No. of } \\
\text { Respondents }\end{array}$ \\
\hline 1 & Administrative Framework for WEEE & Monitoring/Control Agencies & $\mathrm{A}$ & 35 \\
\hline 2 & $\begin{array}{l}\text { End-user Participation in WEEE Management } \\
\text { Activities }\end{array}$ & Monitoring/Control Agencies & A & 35 \\
\hline 3 & $\begin{array}{l}\text { E-Waste Disposal Practices and Patterns by the } \\
\text { Consumers/End-Users }\end{array}$ & End-users/Consumers & B & 137 \\
\hline 4 & $\begin{array}{l}\text { Factors Considered in Adopting Strategies for } \\
\text { Final Disposal of WEEE by Recyclers and Dealers }\end{array}$ & Distributors/ Recyclers & $\mathrm{C}$ & 29 \\
\hline 5 & $\begin{array}{l}\text { WEEE Collection, Handling and Disposal } \\
\text { Methods by Entrepreneurs and Recyclers in South } \\
\text { Eastern Nigeria }\end{array}$ & Distributors/ Recyclers & $\mathrm{C}$ & 29 \\
\hline 6 & $\begin{array}{l}\text { Characterization of E-waste during Generation, } \\
\text { Collection and Disposal of WEEE }\end{array}$ & $\begin{array}{l}\text { Monitoring/Control Agencies; End- } \\
\text { users/Consumers; } \\
\text { Recyclers }\end{array}$ & $\mathrm{A}, \mathrm{B}$ and $\mathrm{C}$ & 201 \\
\hline 7 & $\begin{array}{l}\text { Factors influencing Technical Planning and } \\
\text { Design for WEEE Management Systems }\end{array}$ & Monitoring/Control Agencies & A & 35 \\
\hline
\end{tabular}




\section{RESULTS AND DISCUSSIONS}

The National Environmental (Electrical/Electronics Sector) Regulations S.I. No. 23 of 2011 suggested, amongst other things, ten main categories for electrical and electronic equipment (EEE) covered by the regulations (NESREA, 2011b). From findings on field survey, a list and brief summary of the categories of WEEE was provided accordingly. Table 3 and Figure 1 showed an audit representation for WEEE in South Eastern Nigeria.

A total of 128 Waste Electrical Electronics Equipment (WEEE) were captured in the survey. These were then grouped into ten distinct categories according to the structure presented in the National Environmental (Electrical/Electronics Sector) Regulations, 2011. This categorization is also similar to those classifications of WEEE as used in both the Swiss and Europe Union (EU) legislations (EMPA,
2009). These categories are namely: Large House Appliances (White goods $=16$ ), Small House Appliances (White goods = 19), ICT and Telecommunications equipment (Grey goods $=26$ ), Entertainment and Consumer equipment (Brown goods $=24)$, Lightening equipment $(07)$, Electrical and Electronic tools (with the exception of largescale stationary industrial tools $=15)$, Toys, leisure and sports equipment (04), Medical devices (with the exception of all implanted and infected products = $10)$, Monitoring and control instruments (05), and Automatic dispensers (02). The elicited audit was subjected to face validity in order to show the extent of reliability and degree of confidence that could be placed on the information elicited. However, findings from this study have showed that the above listing for WEEE in South Eastern Nigeria are slightly more in number when compared to previous publications.

Table 3: Audit of WEEE in South Eastern Nigeria

\begin{tabular}{|c|c|c|c|}
\hline S/No. & Category & Items & Total \\
\hline 1. & $\begin{array}{l}\text { Large House Appliances (White } \\
\text { goods) }\end{array}$ & $\begin{array}{l}\text { Industrial refrigerators (cold-storages), fridges, freezers, water heaters, washing } \\
\text { machines, clothes dryers, dishwashers, electric cookers, microwaves, electric } \\
\text { radiators, electric-generators, electric fans, air conditioning appliances and other } \\
\text { fanning, exhaust ventilation and conditioning equipment. }\end{array}$ & 16 \\
\hline 2. & $\begin{array}{l}\text { Small House Appliance (White } \\
\text { goods) }\end{array}$ & $\begin{array}{l}\text { Vacuum cleaners, carpet sweepers, electric irons, toasters, deep-fryers, electric } \\
\text { kettles, grinders/blenders, voltage stabilizers, inverters, coffee mixers, power } \\
\text { cords/strips, chargers, paper shredders, sealing machines and other domestic items } \\
\text { such as hair dryers, shavers, electric toothbrushes, clocks/watches and electric } \\
\text { weighing scales }\end{array}$ & 19 \\
\hline 3 & $\begin{array}{l}\text { ICT and Telecommunications } \\
\text { equipment (Grey goods) }\end{array}$ & $\begin{array}{l}\text { Laptops, notebooks, notepads, personal computer (PC) and its accessories like } \\
\text { CPU, mouse, keyboard, hard drive, zip drive, backup drive and monitors } \\
\text { (including CRT monitor, LCD monitor and LED monitor), Servers, Networking } \\
\text { equipment (Routers), Switches, UPS units, Computer speakers, Laser scanner, } \\
\text { mobile/table phones, printers, copiers, fax machines, calculators, } \\
\text { electrical/electronic typewriters and other telecommunications equipment }\end{array}$ & 26 \\
\hline 4 & $\begin{array}{l}\text { Entertainment and Consumer } \\
\text { equipment (Brown goods) }\end{array}$ & $\begin{array}{l}\text { Televisions (including CRT TVs, LCD TVs, LED TVs, Plasma TVs and Projector } \\
\text { TVs), Overhead Projectors, video cassette recorders (VCRs), radios, Cassette } \\
\text { (Tape) players, Camcorders, DVD players, CD players, IPODs, IPADs and other } \\
\text { Mp3 players, Hi-Fi items, Car stereos, speakers, amplifiers, headsets, X-Box, } \\
\text { Remote controls, musical instruments and other equipment for } \\
\text { recording/reproducing sound or images }\end{array}$ & 24 \\
\hline 5 & Lightening equipment & $\begin{array}{l}\text { Fluorescent lamps (including straight fluorescent lamps, compact fluorescent } \\
\text { lamps), light bulbs, pressure sodium lamps, low pressure sodium lamps, } \\
\text { rechargeable lamps, and non-household lighting for spreading and controlling } \\
\text { light. }\end{array}$ & 07 \\
\hline 6 & $\begin{array}{l}\text { Electrical and Electronic tools } \\
\text { (with the exception of large-scale } \\
\text { stationary industrial tools) }\end{array}$ & $\begin{array}{l}\text { Drilling machines, saw machines, sewing machines, lawnmowers, hedge cutters, } \\
\text { strimmer machines, soldering machine, and equipment for turning, sanding, } \\
\text { grinding, milling, cutting, shearing, welding and spraying for metalwork and } \\
\text { wood processing }\end{array}$ & 15 \\
\hline 7 & Toys, leisure and sports equipment & $\begin{array}{l}\text { Electric trains and car racing toys, hand-held video game accessories, electrical } \\
\text { and electronics sport machines (treadmill) }\end{array}$ & 04 \\
\hline 8 & $\begin{array}{l}\text { Medical devices (with the } \\
\text { exception of all implanted and } \\
\text { infected products) }\end{array}$ & $\begin{array}{l}\text { Cardiology machine, Incubators, Centrifuge, Autoclave, Dialysis machines, } \\
\text { Ventilators and radiotherapy equipment, Microscope, Semi-chemistry Auto- } \\
\text { analyser and other medical electrical and electronic equipment for detecting, } \\
\text { preventing, monitoring and treating patient's illness, injury or disabilities. }\end{array}$ & 10 \\
\hline 9 & $\begin{array}{l}\text { Monitoring and control } \\
\text { instruments }\end{array}$ & $\begin{array}{l}\text { Smoke detectors, gear/control switches, Surge Protectors, thermostats and other } \\
\text { instruments used in industrial installations flow gauges and measuring equipment }\end{array}$ & 05 \\
\hline \multirow[t]{2}{*}{10} & Automatic dispensers & $\begin{array}{l}\text { Automatic dispensers for cold and hot water } \\
\text { Automatic dispensers for hot tea/coffee }\end{array}$ & 02 \\
\hline & & TOTAL & 128 \\
\hline
\end{tabular}


$($ Total Number $(\mathrm{N})$ of respondents $($ End-users + Dealers + Monitoring Agencies $)=201)$

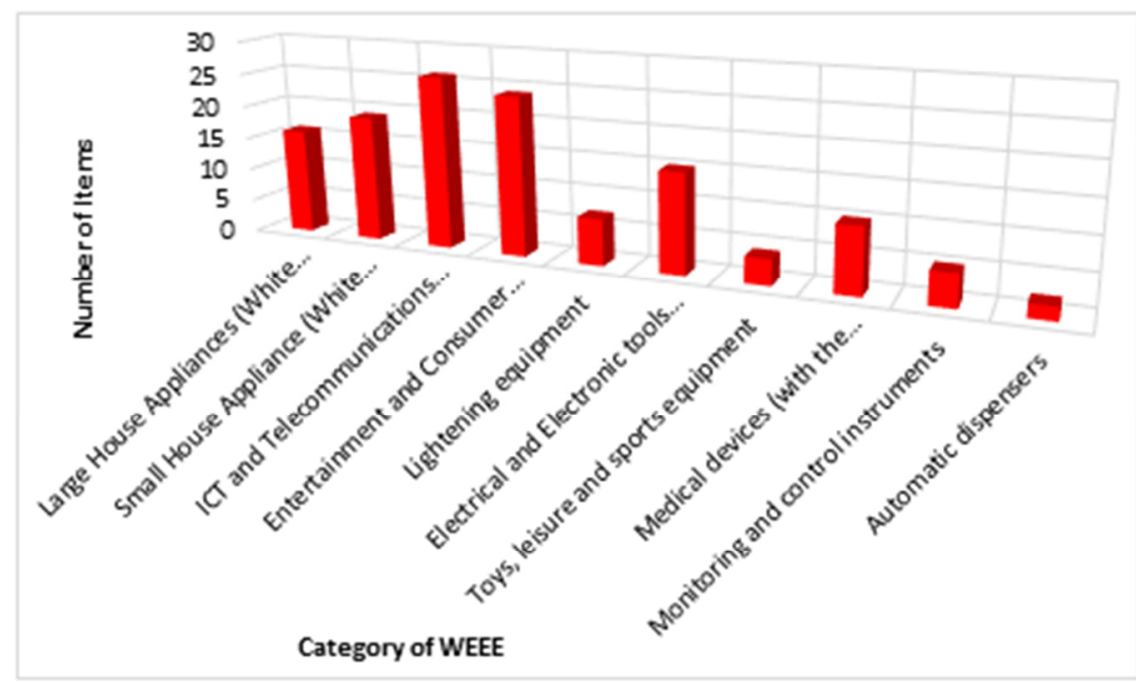

Fig 1: Types and Classification of WEEE in South Eastern Nigeria

The campaign for sustainable management strategies by government, vis-a-vis policy framework for WEEE, is an inclusive feature of the planning process. Field survey revealed that $26(74.39 \%$ ) of the senior/coordinating officers from government monitoring and control agencies acknowledged that government promoted management strategies of source Reduction, Recovery, Reuse, Repair, Recycling, Incineration and Landfilling of WEEE. Nevertheless, 20(57.14\%) of the interviewees differed on the presence of proper Recycling facilities for WEEE in the study area. In addition, these officers are primarily detailed to initiate the characterization of WEEE, encourage source reduction and stratify these wastes before final disposal. On the contrary, the statistics on collection, transfer, intermediate storage, treatment and final disposal of WEEE in the South Eastern Nigeria could be described as impracticable with $22(62.86 \%)$ of these officials affirming to none collation of these wastes. Also, 18(51.43\%) respondents affirmed that the intervallic documentation on WEEE quantity and budgeting are ineffectively carried-out. Hence, we show on Table 4 analysis on hypothesis $\mathrm{H}_{0}$ : There is no significant relationship between the type of WEEE generated and the method of its disposal in South Eastern Nigeria. A linear multiple regression test was carried out on WEEE inventory process, the handling and disposal methods involved (Table 4). For hypothesis $\mathrm{H}_{0}$, the dependent variable is the question on "encouraging Reuse, source Reduction, Recycling, Repair, Recovery, Landfill and Incineration of waste WEEE". While the independent variables included questions on "Carrying out periodic inventory surveys on types of WEEE generated in the region; Collection, Collating, Processing and storing statistics on generated WEEE; as well as Having adequate periodic documentation on WEEE quantity and budgeting to support management process".

The Regression Criteria $=$ Pin (0.05). The comparable values for regression inferential statistics Beta $(\beta)$ for $\mathrm{H} 02$ are $\beta 1=-1.554, \beta 2=-1.771$ and $\beta 3=2.633$ with their respective p-values as $\mathrm{p} 1=0.463$, p2 $=0.622$, and $\mathrm{p} 3=0.578$, while the R-square is 0.608 or R2 = $61 \%$. Both questions on "Carrying out period inventory surveys on types of WEEE generated; and the Collection, Collating, Processing and Storage of Statistics on generated WEEE" have negative values for $\beta$ which implies insignificancy. Although, the question on "Does your organization have adequate period documentation on WEEE quantity?" had a positive value for $\beta 3=2.633$ and the $p$-value tabulated ( $\mathrm{p} 3=0.578)$ which is less than $\beta 3$, the significance of the variables is therefore determined together as a group of the three $\beta$ values. Therefore, we accept $\mathrm{H}_{0}$ : There is no significant relationship between the type of WEEE generated and the method of its disposal in South Eastern Nigeria, since two of the three values of calculated $\beta$ are insignificant.

Conclusions: A total of 128 WEEE were captured in the survey. These were then grouped into ten distinct categories according to the structure presented in the National Environmental (Electrical/Electronics Sector) Regulations, 2011. This categorization is similar to that used by both the Swiss and Europe 
Union (EU) legislations. Hence, there is need to commence annual or periodic inventory on WEEE types and quantity. This would enable stakeholders to assess, project and proffer workable management strategies that are evident-based.

Table 4: Summary of Statistical Test for Hypothesis $\mathrm{H}_{0}$

REGRESSION /MISSING LISTWISE /STATISTICS COEFF OUTS R ANOVA /CRITERIA=PIN(.05) POUT(.10) /NOORIGIN /DEPENDENT EncDReuseSourceRedRecycleRepairRecLandfillnIncineratnofWEEE

/METHOD=ENTER CarOuPeriInvSurvOnTyOfEwastGen ColleCollaProceDStoStatOnGeneEwaste HavAdeqPeriDocOnEwastQuan. Regression

\begin{tabular}{|c|c|c|c|}
\hline Model & Variables Entered & Variables Removed & Method \\
\hline 1 & $\begin{array}{l}\text { Have adequate period documentation on WEEE quantity?, Carry period inventory } \\
\text { surveys on types of WEEE generated, Collect, Collate, Process and Store Statistics on } \\
\text { generated WEEE? }\end{array}$ & & Enter \\
\hline
\end{tabular}

a. Dependent Variable: Encourage the Reuse, Source Reduction, Repair, Recovery, Landfill and Incineration of WEEE

b. All requested variables entered.

\begin{tabular}{|c|c|c|c|c|}
\hline Model & R & R Square & Adjusted R Square & Std. Error of the Estimate \\
\hline 1 & $.780^{\mathrm{a}}$ & .608 & -.567 & 9.07127 \\
\hline
\end{tabular}

a. Predictors: (Constant), Have adequate period documentation on WEEE quantity?, Carry period inventory surveys on types of WEEE generated, Collect, Collate, Process and Store Statistics on generated WEEE?

ANOVA $^{\mathrm{a}}$

\begin{tabular}{|c|c|c|c|c|c|}
\hline Model & Sum of Squares & $\mathrm{df}$ & Mean Square & $\mathrm{F}$ & Sig. \\
\hline Regression & 127.712 & 3 & 42.571 & .517 & $.741^{b}$ \\
\hline Residual & 82.288 & 1 & 82.288 & & \\
\hline Total & 210.000 & 4 & & & \\
\hline
\end{tabular}

a. Dependent Variable: Encourage the Reuse, Source Reduction, Repair, Recovery, Landfill and Incineration of WEEE

b. Predictors: (Constant), Have adequate period documentation on WEEE quantity?, Carry period inventory surveys on types of WEEE generated, Collect, Collate, Process and Store Statistics on generated WEEE?

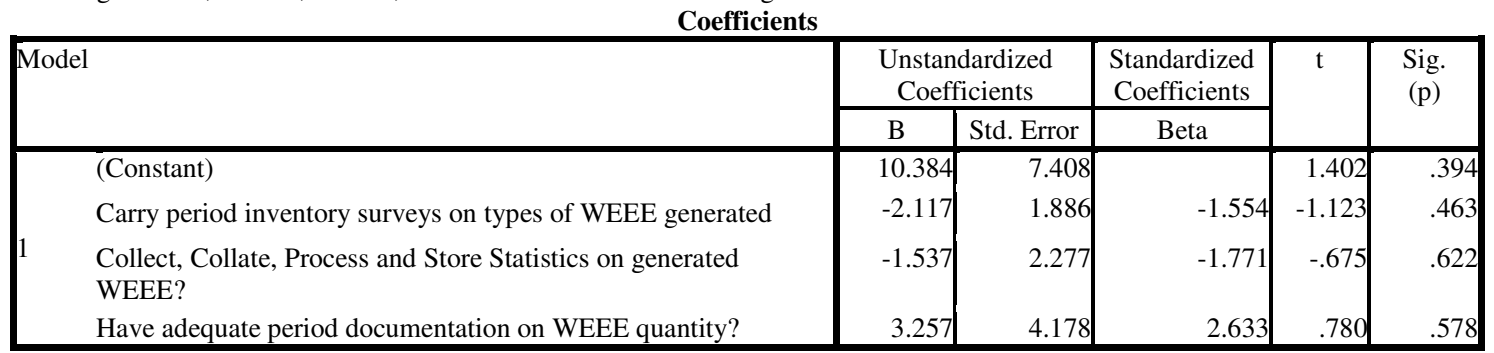

Dependent Variable: Encourage the Reuse, Source Reduction, Repair, Recovery, Landfill and Incineration of WEEE

\section{REFERENCES}

Alo B. I. (2009). Best Available Environmentally Sound Management Practices In E-Waste Control. In proceedings of the International Conference on E-Waste Control Abuja, Nigeria: The Abuja Platform on E-Waste. Abuja: National Environmental Standards and Regulations Enforcement Agency (NESREA), Abuja.

Ayodeji Odeyingbo Olusegun (2011). Assessment of the flow and driving forces of used electrical and electronic equipment into and within Nigeria. Master Thesis. Environmental and Resource Management. BTU Cottbus. Pp 1-104 Available at:

http://isp.unu.edu/publications/scycle/files/maste r-thesis-olusegun.pdf [Last accessed 21, January, 2013]

Basel Convention (2011). Where are WEee in Africa? Findings from the Basel Convention. Ewaste Africa Programme. Secretariat of the Basel Convention (SBC), viewed 04, January, 2013, pp. 1-50. Available at: http://www.basel.int [Last accessed 15, January, 2013]

Dittke Susanne (2009). Opportunities in E-waste. In proceedings of the International Conference on E-Waste Control Abuja, Nigeria: The Abuja Platform on E-Waste. Abuja: National Environmental Standards and Regulations Enforcement Agency (NESREA) 
EMPA (2009). E-waste: Hazardous Substances in eWaste. Available at: http://ewasteguide.info/introduction/e-waste. [Last accessed 15, January, 2013]

E-Waste Association of South Africa, eWASA, (2009). Towards Sustainable Environmentally Sound e-Waste Management. In proceedings of the International Conference on E-Waste Control Abuja, Nigeria: The Abuja Platform on E-Waste. Abuja: National Environmental Standards and Regulations Enforcement Agency (NESREA).

GFMECD (1995). Environmental Handbook Documentation on Monetary and Evaluating Environmental Impacts. Volume 1. GmbH, Eschborn: Deutsche Gesellschaft fur. Technische zusammenarbeit. Pp. 320 - 391

National Environmental Standards and Regulations Enforcement Agency, NESREA, (2011a). Global Perspective of E-Waste: A Keynote Address by Dr. (Mrs) Ngeri S. Benebo Jp., at the EKO Ewaste summit. Retrieved from http://elring.org/DG\%20speech\%20at\%20EKO\% 20Ewaste\%20summit\%2009022011.pdf.

NESREA. (2011b). The National Environmental (Electrical/Electronic Sector) Regulations S.I. No. 23 of 2011, Federal Republic of Nigeria Official Gazette No. 50 Lagos - 25th May, 2011, The Federal Government Printer, Lagos, Nigeria. FGP75/72011/400(OL47).

Oh C. J., Lee S. O., Yang H. S., Ha T. J, Kim M. J. (2003). Selective leaching of valuable metals from waste printed circuit boards. Journal of Air and Waste Management association, 53, $897-$ 902.

Okorhi O. J., Olamade O.; Aderemi H. O.; Obaze I.; Abia-Bassey N. (2012). Strategies for Sustainable Management of Solid Wastes: A Case Study of Industrial and Commercial Processes in Delta State. In proceedings the 11th Annual Nigerian Materials Congress (NIMACON 2012), Ile-Ife. November 20-24, 2012. Paper Code: P4-09144, Page 140 - 148.
Okorhi O. J.; Amadi-Echendu J. E.; Aderemi H. O.; Otejere J. (2015). Technology Paradigm for EWaste Management in South-Eastern Nigeria. Proceedings of the 24th International Conference on Management of Technology (IAMOT 2015) holding at The Westin, Cape Town, South Africa. Retrieved from http://iamot2015.com/2015proceedings/documen ts/P099.pdf.

Okorhi O. J.; Omotor D. A.; Aderemi H. O.; Abang S. I. (2017). Wastes from Industrialized Countries: A Socio-economic inquiry on Sustainable Management of E-waste for the Recycling Sector in Nigeria. Proceedings of the $3^{\text {rd }}$ AfricaLics International Conference: Emerging Innovation Systems for Sustainable Industrial Development in Africa held between 27 and 29 November, 2017 at the Oran University 2, Oran, Algeria.

The Guardian (2012). Domestic consumption Fuels: Africa's e-waste imports, says report. The Environment. The Guardian, Monday, February 13, 2012. Pp. 48-49. Available at: http://www.ngrguardiannews.com [Last accessed 13, February, 2013]

United Nations. (2011). The Millennium Development Goals Report 2011. New York: United Nations. ISBN 978-92-1-101244-6. Pp 58-64.

Vanguard (2013). FG orders return of toxic ship to UK. Vanguard On-line News: 12th January, 2013. Available at: http://www.vanguardngr.com/2013/01/toxic-wastefg-to-sanction-ship-owners [Last accessed 13, February, 2013] 